\title{
Szkoła publiczna między neoliberalizmem a narodowym konserwatyzmem
}

\begin{abstract}
STRESZCZENIE
W tekście przypominamy historyczne konteksty przemian szkolnictwa publicznego, by przez ich przywołanie ukształtować dystans konieczny dla poddania namysłowi współczesnych przesileń i przeobrażeń zachodzących w tym obszarze. Jednym z głównych zadań powszechnej i jednolitej szkoły w modernizującej się Europie było zapewnienie równości startu edukacyjnego wszystkim dzieciom. W rzeczywistości neoliberalnej zadanie to przestało być oczywiste i przy istotnym udziale rodziców podważone zostały podstawy publicznego charakteru szkoły. Rodzice z politycznie i ekonomicznie dominującej klasy średniej, dążący do wypracowania dla swego potomstwa przewagi nad innymi dziećmi, nie chcą szkoły publicznej. Jej obrona jest zatem łatwo marginalizowana. Na przykładzie niedawnych reform (np. amerykańskich) pokazujemy, jak szkoły przestają być miejscami, w których ludzie należący do zróżnicowanych warstw czy klas społecznych mogą tworzyć wspólny świat. Z tej perspektywy analizujemy zagadnienia wynikające z zakwestionowania neoliberalnej polityki społecznej, które dokonało się w ostatnich latach. W Polsce znajduje to wyraz m.in. w zwycięstwie wyborczym ugrupowania (Prawo i Sprawiedliwość - PiS), stawiającego na przywrócenie pomijanym dotąd grupom społecznym należnego miejsca w przestrzeni publicznej. Można by się spodziewać, że styl poprzedniej polityki edukacyjnej zostanie w związku z tym zastąpiony polityką bardziej egalitarną, równościową, zapobiegającą
\end{abstract}

1 Maria Mendel, Wydział Nauk Społecznych, Uniwersytet Gdański, Polska, e-mail: maria.mendel@ug.edu.pl, ORCID ID: https://orcid.org/0000-0002-4022-5402.

2 Tomasz Szkudlarek, Wydział Nauk Społecznych, Uniwersytet Gdański, Polska, e-mail: tomasz.szkudlarek@ug.edu.pl, ORCID ID: https://orcid.org/0000-0001-9308-7106. 
nieuzasadnionym merytorycznie selekcjom ograniczającym szanse życiowe „gorzej urodzonych” dzieci. Polityka oświatowa PiS zmierza jednak w stronę dokładnie przeciwną i rozbudowuje strategie selekcyjne systemu (elitarne licea, koniec z „masowym” dostępem do szkół etc.). Próbując dociec przyczyn tej sprzeczności, ogniskujemy uwagę na profitach, które w publicznym dyskursie przynosi - praktykowane aktualnie - zastępowanie społeczeństwa przez naród.

\title{
Słowa kluczowe:
}

szkoła publiczna, równość, godność, neoliberalizm, narodowy konserwatyzm

\begin{abstract}
In the text, we first recall the historical contexts of changes in public education, by recalling them to shape the distance necessary to reflect on the current solstices and transformations taking place in this area. One of the main tasks of a universal and uniform school in a modernizing Europe was to ensure equal educational start for all children. In neo-liberal reality, this task ceased to be obvious, and with the significant participation of parents, the foundations of the school's public character were undermined. Parents from a politically and economically dominant middle class, seeking to gain an advantage over their children, simply do not want public school. The public school defense is therefore easily marginalized. Using the example of recent reforms (e.g. American), we show how schools are no longer places where people belonging to different layers or social classes can create a common world. From this perspective, we analyze issues arising from the questioning of neoliberal social policy that has taken place in recent years. In Poland, it finds expression in, among others in the electoral victory of the grouping (Law and Justice - PiS), aiming to restore the previously overlooked social groups to their rightful place in public space. One could expect that the style of the previous educational policy will therefore be replaced by a more egalitarian, equality policy, preventing unjustifiable selections limiting the life chances of 'less-born' children. However, PiS education policy goes in the opposite direction and expands the system's selection strategies (elite high schools, no more "mass" access to schools, etc.). Trying to find out the reasons for this contradiction, we focus our attention on the profits that in public discourse brings - as practiced today - the replacement of society by the nation.
\end{abstract}

\section{Keywords:}

public school, equality, dignity, neoliberalism, national conservatism 


\section{KONTEKSTY I TEZY}

Rozpocznijmy od krótkiej uwagi natury historycznej. Pojęcie szkoły publicznej można wiązać z kilkoma nurtami rozwoju systemów oświatowych. Pierwszy z nich nazywamy filantropijnym, wiąże się on z organizowaniem przez środowiska elitarne rozmaitych form edukacji instytucjonalnej dla niższych warstw społecznych. Taką genezę ma angielskie pojęcie public school, które zwykle oznaczało szkołę prywatną przeznaczoną dla warstw ludowych. W szkole takiej nie kształciły się dzieci fundatorów tego rodzaju instytucji, ich edukacja miała inne formy - przede wszystkim związane z zatrudnianiem nauczycieli w domu ucznia, a także z edukacyjnymi podróżami, kształceniem w „domu obcym” (u zaprzyjaźnionej lub spokrewnionej rodziny), z wyjazdami na zagraniczne studia, etc. Fundatorzy tego rodzaju szkół publicznych działali w intencji pro bono publico, przy czym owo dobro publiczne mogło być pojmowane rozmaicie - w kategoriach religijnych, moralnych czy różnorodnie ujmowanych wymiarach sprawności. Druga forma to kształcenie organizowane przez działające na rozległych obszarach instytucje przede wszystkim kościoły, w tym dedykowane celom edukacyjnym zgromadzenia zakonne. Kolejna forma obejmowałaby działania edukacyjne podejmowane przez samoorganizujące się dla wielorako pojmowanego własnego dobra środowiska ludowe: towarzystwa trzeźwości, kółka biblijne, później stowarzyszenia robotnicze i inne grupy samokształceniowe, rozwijające się przede wszystkim (ale nie tyko) w tych krajach, w których dominującą pozycję zyskiwały kościoły reformowane. Wreszcie mamy fenomen organizowanej przez nowoczesne państwa edukacji powszechnej, adresowanej do wszystkich grup społecznych na identycznych zasadach, zwykle przy traktowaniu edukacji na szczeblach uznanych za podstawowe za prawnie regulowany obowiązek. Podstawową różnicą między tą ostatnią, a wszystkimi poprzednimi formami edukacji publicznej jest jej totalny w zamierzeniach zasięg, jej powszechność. Jak widać pojęcie edukacji publicznej rozumiemy tutaj jako dotyczące tych form kształcenia, które dostępne sq publicznie, to znaczy mogq być realizowane przez osoby niekoniecznie należące do środowisk elitarnych. Szkoła powszechna jest natomiast specyficzną dla nowoczesności formą edukacji publicznej - szkołą obowiązkową dla wszystkich. Pojawienie się tego fenomenu należy wiązać z trzema - po części - historycznie zbieżnymi, ale istotowo odmiennymi motywami: z dążeniami emancypacyjnymi warstw ludowych (protestanckie ruchy akcentujące powszechne prawo do zbawienia, późniejsze ruchy chłopskie, spółdzielcze, robotnicze etc); z oświeceniowym republikanizmem (jak wspominał G. Washington, jeśli elity mają „podzielić się” władzą z ludem, to lud musi zostać uprzednio oświecony: społeczeństwo republikańskie zakładające powszechne 
obywatelstwo polityczne musi składać się z jednostek racjonalnych, a to wymaga obowiązku kształcenia) wreszcie - z pojawieniem się ideologii nacjonalistycznych i z budową państw narodowych (edukacja powszechna ma w tym wypadku wymiar tworzenia świata wspólnego, pewnej przestrzeni symbolicznej podzielanej przez wszystkie warstwy narodu).

Dlaczego przypominamy te historyczne konteksty? Sądzimy, że ich przywołanie umożliwi nam nabycie pewnego dystansu koniecznego dla poddania namysłowi współczesnych przesileń i przeobrażeń zachodzących w obszarze szkolnictwa publicznego ${ }^{3}$.

Zatrzymamy się najpierw na jednym ze skutków społecznych reform podejmowanych od lat 80. XX wieku, kiedy to borykające się z ówczesnym kryzysem państwa Zachodu z nadzieją przyjęły nowy język opisu społecznej rzeczywistości. Ekonomiczna zapaść wywołana przenoszeniem produkcji przemysłowej (a z nią miejsc pracy i przychodów z podatków) do Azji uznana została wtedy za skutek nie tyle procesów globalizacyjnych, które są niezbędne dla funkcjonowania kapitalistycznej gospodarki, ile spóźnionej na nie reakcji ze strony społeczeństw Zachodu. Jak chętnie mówiono, społeczeństwa te nie zauważyły w porę, że rozbudowane zabezpieczenia socjalne wywindowały koszty zatrudnienia na poziom wielokrotnie przewyższający koszty pracy we wschodzących gospodarkach Azji. Lekarstwem na kryzys powinna być zatem redukcja wydatków socjalnych oraz stworzenie inwestycyjnych zachęt dla kapitalistów (obniżenie podatków, deregulacja prawa pracy, tanie kredyty etc.). Dawno zapomniana doktryna leseferyzmu (minimalne państwo i zniesienie ograniczeń inicjatywy gospodarczej) stała się językiem diagnozy tego, co zaszło (zapomniano o prawach ekonomii), i nadziei na to, co miało nadejść (gospodarcze ożywienie przez uwolnienie inicjatywy i zmuszenie „socjalnych pasożytów” do roboty). W tym języku przedefiniowano pojęcia dotyczące nie tylko ekonomii, ale i całości życia społecznego: społeczeństwo obywatelskie ma zostać „upodmiotowione” i przejąć od państwa funkcje socjalne, edukacyjne, kulturalne itp. - mają być one realizowane na drodze społecznej samoorganizacji, a nie przez należące do państwa instytucje. Typowe dla doktryny liberalnej idee efektywności i rynkowej regulacji relacji między podmiotami odświeżono na użytek podmiotów gospodarczych i wynaleziono na użytek podmiotów społecznych. Tam, gdzie nie było rynku (w służbie zdrowia, w transporcie publicznym, w szkolnictwie, w opiece społecznej), wprowadzono jego symulacje, na przykład

${ }^{3}$ Więcej o tych przeobrażeniach i ich uwarunkowaniach piszemy w wielu innych swoich tekstach. Część z nich wykorzystujemy w tej wypowiedzi, miksując, przeformułowując ich fragmenty itp. (Szkudlarek, 2001; Mendel, Szkudlarek, 2013; Mendel, 2015; Mendel, 2017). 
sztucznie tworząc konieczność konkurencji między szkołami lub szpitalami (Szkudlarek, 2001). Realizacja owych uwolnień okazała się bardzo korzystna jedynie dla najsilniejszych globalnych graczy, a wiązane z deregulacją nadzieje na uwolnienie życia społecznego ze sztywnych gorsetów biurokracji okazały się naiwne. Rynek wymaga bowiem miar ekwiwalencji wymiany, jakichś zasad, które pozwolą ustalić, ile buraków należy się za beczkę piwa lub kurczaków za usługę prawnika. Bez względu na to, jak określimy tego rodzaju parytety, ich podstawowym warunkiem musi być ich mierzalność. Wprowadzenie zasad rynku do edukacji, medycyny czy służb społecznych musiało zatem doprowadzić do mozolnego procesu ich parametryzacji, do narzucania tym sferom mierzalnych kryteriów wartości i efektywności. Biurokracja zajmująca się dystrybucją środków publicznych nie zniknęła, za to pojawiła się jeszcze bardziej drobiazgowa biurokracja szacowania efektywności i kontroli jakości „usług społecznych” pełnionych przez liczne, konkurujące teraz podmioty.

Proces ten trwa nadal i nie widać jeszcze końca jego rozwoju. Prywatyzacją, urynkowieniem i parametryzacją wartości obejmowane są dotychczas nieobjęte lub nie w pełni objęte nią dziedziny (na przykład twórczość naukowa i uczenie się całożyciowe). Jeśli wzbudza to zauważalny opór, to chyba głównie z powodu gwałtownego przyrostu pracy związanej właśnie z obsługą aparatu parametryzacji. Sama istota rywalizacji, prywatyzacji czy - szerzej - sam pomysł określania życia społecznego przy pomocy języka kapitału (intelektualnego, ludzkiego, kulturowego...) nie ulega jednak wyraźnemu zakwestionowaniu. Tymczasem głęboki kryzys przeżywają ekonomiczne podstawy tego projektu, a przede wszystkim typowe dla gospodarek postindustrialnych uczynienie z rynków finansowych autonomicznej i nastawionej na zysk sfery gospodarki. Kryzys bankowy został zażegnany przez interwencje państw (nagle zwolnionych z zakazu interweniowania w rynkowe mechanizmy gospodarcze), co doprowadziło do dramatycznego deficytu finansów publicznych. Logika kapitału nałożona na sferę publiczną zamiast ulec w tej sytuacji zakwestionowaniu, ulega intensyfikacji: konieczność redukcji budżetowych wzmaga presję na deregulację, prywatyzację i parametryzację wszystkiego, co ociera się o finansowanie publiczne.

Logika rynku prowadzi do - w naszej ocenie - bardzo ryzykownych skutków funkcjonowania systemu edukacji. Mechanizmy rynkowe nie mogą funkcjonować bez wolnego wyboru oferowanych produktów, a logika wyboru szkoły prowadzi w oczywisty sposób do skutków segregacyjnych. Mechanizm ten był opisywany wielokrotnie i wydaje się, że jest on znakomicie rozpoznawany i akceptowany przez silniejszą, zamożniejszą część społeczeństwa: rodzice cieszący się wyższym statusem społeczno-ekonomicznym świadomie wybierają dla swoich dzieci szkoły 
uzyskujące w opomiarowanych rankingach wyższe pozycje i muszą zdawać sobie sprawę z tego, że w tych szkołach ich dzieci nie spotkają się z uczniami z rodzin o niższym statusie. Co dość interesujące, sytuacja taka jest spokojnie akceptowana, nie ma w Polsce wyraźnych śladów buntu wobec takiego rozwarstwiania edukacji publicznej. W języku teorii Pierre’a Bourdieu (Bourdieu, Passeron, 1990) takie określa się zjawisko mianem reprodukcji nierówności społecznych. Teoria Bourdieu nie pozostawiała wątpliwości co do tego, że jest to proces społecznie szkodliwy i sprzeczny z misją oświaty publicznej. Jednym z głównych zadań powszechnej i jednolitej szkoły w modernizującej się Europie było zapewnienie równości startu edukacyjnego wszystkim dzieciom. Bez wyraźnych głosów protestu i bez znaczącej publicznej dyskusji na ten temat zrezygnowaliśmy z tej funkcji szkoły. Podważa to podstawy jej publicznego charakteru, przy braku znaczącego oporu wobec demontażu tego wymiaru edukacji. Rodzice z politycznie i ekonomicznie dominującej klasy średniej, dążący do wypracowania dla swego potomstwa przewagi nad innymi dziećmi, po prostu nie chcą szkoły publicznej. Jej obrona jest zatem łatwo marginalizowana. Rozwiniemy dalej to stanowisko.

\section{RODZICE Z KLASY ŚREDNIEJ NIE CHCĄ SZKOŁY PUBLICZNEJ... SPOŁECZNO-EKONOMICZNE UWARUNKOWANIA PRZEMIAN}

Ruchy rodzicielskie skutkujące powstawaniem nowego typu szkół opierają się na rodzicach z klasy średniej. W warunkach przesileń społeczno-ustrojowych, kiedy zwyczajowo odżywa postulat uspołecznienia szkoły, aktywnie podejmują go zwykle rodzice reprezentujący klasę średnią. Obok reprezentantów klasy niższej i wyższej, z różnych powodów niezainteresowanych zmianą edukacyjnego standardu, są jedynymi, którym z uwagi na społeczny awans naprawdę zależy na zmianie. To też jedyni, którzy są gotowi poświęcić temu nie tylko własne środki, ale i czas, energię, kreatywność. W dwóch momentach polskiej transformacji widać to szczególnie jaskrawo. Chodzi o lata 90. XX w. przeniknięte ideą nowej, popeerelowskiej oświaty i żywiołowy rozkwit szkół niepublicznych (Jung-Miklaszewska, Rusakowska, 1995), a także lata po wejściu Polski do Unii Europejskiej w roku 2004, kiedy intensywnemu doganianiu Zachodu towarzyszyła silna polaryzacja klasowa, a dystynkcje budowane na kryteriach edukacyjnych stały się kluczowe w polach aspiracji rosnącej klasy średniej. Z tym drugim momentem splotły się tendencje prywatyzacyjne w sektorze edukacji. Szkoła odpowiadająca na partykularne potrzeby zaczęła uciekać od publicznej kontroli, stale czerpiąc z publicznych zasobów. Charakterystycznie zaczęła przy tym gubić nazwę lub zmieniać ją przez 
dodawanie przymiotników itp. (Mendel, 2015). Rodzice z klasy średniej - angażując swój czas i opłacając czesne - od tamtego mniej więcej czasu współtworzą liczne szkoły przymiotnikowe - tzw. akademie dobrej edukacji (źródło internetowe 1) czy szkoły demokratyczne (źródło internetowe 2) i inne. Poza tym, zachęcani do korzystania z prawa do edukacji domowej, finansują działalność placówek edukacyjnych, które oferują generalnie to, co daje „tradycyjna” szkoła, jednak nie poddając się rygorom w zakresie otwartej rekrutacji, czy publicznego nadzoru.

Wychodząc poza polski krajobraz oświatowy można zwrócić w tym miejscu uwagę na USA, gdzie symptomy zmiany w podejściu do szkolnictwa publicznego można było zaobserwować m.in. w gorącej dyskusji o parental choice i potrzebie alternatywnej szkoły . Dyskusji skutkującej w latach 90. ubiegłego wieku zróżnicowaniem organizacyjnym szkolnictwa publicznego i - w rezultacie - przenoszeniem środków publicznych do sektora prywatnego, np. za pośrednictwem tak zwanych charter schools, szkół kontraktowych - czarterowych. W badaniach historii amerykańskiego szkolnictwa i w komparatystycznych studiach zdywersyfikowanych instytucji edukacyjnych charter school definiowana jest jako „szkoła publiczna kierowana przez grupę społeczną w oparciu o specjalny statut - umowę (charter), sygnowaną przez państwo lub lokalną radę szkolną”. Angielska nazwa charter wyraża zarówno tę statutową specyfikę (charter oznacza Kartę, jak Wielka Karta Swobód, czyli The Great Charter), jak i prawa (np. city charter oznacza prawa miejskie), którymi cieszą się te szkoły i które je odróżniają, czyniąc je wyjątkiem wśród „tradycyjnych” szkół publicznych. Charter oznacza także określony program, plan działania, według którego pracują, oraz - znaczące w kontekście prywatyzacyjnym - ich wynajęcie ${ }^{5}$. Stąd pewnie zdarza się, że w języku polskim tłumaczy się charter school jako szkołę kontraktowq ${ }^{6}$. Organem prowadzącym taką szkołę może być organizacja pozarządowa czy firma; podmiot działający for profit. Rodzice mogą płacić w nich czesne (reguluje to statut, na który się godzą) i szkoła może zarabiać na swoje potrzeby.

Szkoły czarterowe często tworzą alternatywne rozwiązania edukacyjne niedostępne w typowych (regular) szkołach publicznych” (Ornstein et al., 2011, s. 209). Wraz z prawnym wprowadzeniem szkół charter w USA na poziomie federalnym i stanowym powołano rady do spraw reform szkolnych, praktycznie

${ }^{4}$ Przedstawiana dalej część tekstu zawiera fragmenty analiz amerykańskiego szkolnictwa (Mendel, 2017).

${ }^{5} \mathrm{~W}$ języku polskim także używamy słowa: wyczarterować.

6 Zob. m.in. tłumaczenie Agnieszki Kościańskiej i Michała Petryka (Cervinkova, Gołębniak, 2010, s. 440). 
upowszechniające te szkoły w całym kraju. Zarządzanie nimi szybko przybrało postać korporacyjną, w sensie zwierzchnictwa całkowicie wolną od kontroli ze strony lokalnych samorządów, których wpływ na szkoły na własnym terenie w ten sposób został nie tylko ograniczony, ale wręcz zablokowany.

Stąd ruchy społeczne kontestujące taki stan rzeczy walczą o odzyskanie (reclaim) szkół i przywrócenie ich publicznej jakości. Jeden z nich, skupiający ponad siedmiomilionową społeczność Alliance to Reclaim Our Schools (AROS), manifestuje potrzebę nadania odzyskanym szkołom cech „zrównoważonej szkoły społecznej” (Sustainable Community School), na tyle silnych, by zdołały przezwyciężyć rozprzestrzeniający się model korporacyjny. Różnice opisywane są w następujący sposób: „Model korporacyjny reform szkolnych promuje raczej zamykanie szkół niż ich ulepszanie. Zamiast rozszerzać wsparcie dla uczniów w ramach szkół sąsiedzkich, kieruje zasoby do szkół czarterowych, nie pociągając ich przy tym do odpowiedzialności. Skutkuje to pogłębianiem nierówności i nie stanowi rozwiązania problemów [...] Nasz model opiera się na prawie każdego dziecka do udziału w wysokiej jakości, społecznej i zrównoważonej szkole w ich sąsiedztwie"”.

Model korporacyjny ma się jednak dobrze i liczba wpisujących się w niego szkół i uczniów do nich uczęszczających stale rośnie ${ }^{8}$. Szkoły czarterowe są finansowane ze środków publicznych oraz „,sponsorskich”, które stanowią możliwy, ale niepewny wkład do ich budżetu9 . Stąd - z uwagi na logikę profitową - tendencja do oszczędnego gospodarowania i mieszczenia się z wydatkami w ramach dotacji publicznej jest w tych szkołach powszechna. W związku z tym wynagrodzenia nauczycieli utrzymują się na raczej minimalnym poziomie i szkoły te mają problemy z pozyskaniem wysoko kwalifikowanej kadry; inwestycje przestrzenne nie są dla tych szkół charakterystyczne (najczęściej adaptują używane w innych celach obiekty, nieadekwatne do edukacyjnych potrzeb) itp. (Ornstein et al., 2011: 208-209). Prowadzący szkoły charters nie mają przy tym raczej wygórowanych ambicji infrastrukturalnych - niedrogi lokal pozwala zarobić na szkole więcej.

7 AROS: The Schools Our Children Deserve Uniting to Win Sustainable Community Schools (źródło internetowe 3)

8 Pisze o tym zespół badaczy z CREDO, jednostki badawczej Stanford University, rejestrującej stan rozwoju charters do roku 2012-2013 (na ten moment w amerykańskich szkołach charters uczyło się 2,3 miliona uczniów) (Berliner et al., 2014).

9 Badacze jednocześnie stwierdzają, że w charters „odpowiedzialność i zobowiązania sponsorów często nie są jasno przez nich określone [...] co prowadzi do nieporozumień i zamieszania” (Ornstein et al., 2011, s. 210). 
Charters jednak przyciągają. Dają wybór, ale jest to w istocie wybór ograniczony jedynie do tych rodziców, którzy mogą wybierać między szkołą prywatną a religijną; do klasy średniej, którą po prostu na wybór stać. W efekcie wybierając szkołę charter - według demitologizującej ją oceny nie lepszą i nie gorszą od szkoły „tradycyjnej” (Berliner et al., 2014) - zasilają zorientowane na zysk administrowanie publicznymi zasobami. W tym kontekście raport z badania kultury organizacyjnej Charter School Management Organizations (CMOs), pokazujący praktyki zarządzania szkołami czarterowymi w USA, ocenia je jako kontrowersyjne (Stahl, 2018). Wskutek tych praktyk ugruntowywany jest neoliberalny model szkoły jako inwestycji nakierowanej na produkcję neoliberalnych podmiotowości. Ma to miejsce przy głośnej retoryce równości i sprawiedliwości społecznej z jednej strony i - z drugiej - pochwale korporacyjnych praktyk, przedstawianych jako jedyne zdolne do poprawy kondycji szkolnictwa USA (Stahl, 2018).

\section{MIĘDZY NEOLIBERALIZMEM A NARODOWYM KONSERWATYZMEM}

W związku z zachodzącymi przemianami w USA mówi się o zjawisku „czarteryzacji” (charterization), które przybliżymy tu, widząc w nim przyczynek do uchwycenia pewnych regularności, które na poziomie teoretycznym mogą opisywać trwające w szkolnictwie publicznym przesilenia. Czarteryzacją nazywa się głęboką transformację systemową, flagowo związaną z dywersyfikacją szkolnictwa i restrukturyzacją sieci szkolnych (Daly, Finnigan, 2016; Buras, 2015) ${ }^{10}$. Polega ona na przemieszczeniach ludzi oraz kapitału, dokonujących się poza demokratycznymi standardami i przeorganizowujących społeczną rzeczywistość w stronę pogłębiania nierówności. Czarteryzacja posiada swoją chwytliwą logikę; racjonalność budowaną na ostrej opozycji wobec edukacji i szkoły, która określana mianem „tradycyjnej” jawi się jako przestarzała i nieodpowiednia na aktualne czasy, silnie wymagająca zmiany, a najlepiej zastąpienia jej inną, lepszą. Główni adresaci tego typu konfrontacji to - jak okazuje się m.in. z przeglądów klienteli charters (Buras, 2015) - amerykańska klasa średnia, wiecznie aspirująca i budująca się na silnych dystynkcjach.

W czarteryzacji chodzi o zorganizowaną w neoliberalnym formacie prywatyzację, postępującą w oparciu o populistyczną, neokonserwatywną retorykę (Ravitch, 2013; Stahl, 2018). To for profit dokonująca się, ustawiczna rekonstrukcja amerykańskiego szkolnictwa publicznego, zachodząca z wykorzystaniem szkół

10 Zachodzi ona według tak zwanego modelu „portfolio”, który stanowi główną strategię zmian. 
typu charters i im podobnych, w szerszej perspektywie przynosząca zmiany strukturalne, negatywne ze społecznego punktu widzenia i wyrażające rozbrat z demokracją. Administracja Donalda Trumpa rozwija tę rekonstrukcję i jej służy. Dla przykładu, stanowisko ministra edukacji w USA otrzymała multimilionerka Betsy DeVos, mówiąca o sobie z dumą, że nigdy nie uczęszczała do szkoły publicznej zakończyła edukację na licencjacie (będąc pierwszym w USA ministrem edukacji bez magisterium), nigdy nie korzystała z państwowego wsparcia swojej edukacji, a jej pasją jest pomoc rodzicom w znajdywaniu - poprzez bony edukacyjne i szkoły typu charters - alternatyw wobec tradycyjnego szkolnictwa publicznego (źródło internetowe 4). Amerykański senat, pomimo republikańskiej większości, po równo podzielił się w głosowaniu nad zatwierdzeniem tej - uznanej za jedną z najbardziej w tym czasie kontrowersyjnych - decyzji prezydenta Trumpa. Kandydatura przeszła jednym głosem, należącym do wiceprezydenta (51 do 50). Przedtem Senat odbył całonocną sesję, na której wśród wielu argumentów przeciw zatwierdzeniu najczęściej padały te o bezkrytycznym poparciu kandydatki dla bonów na naukę w szkołach prywatnych oraz o braku doświadczenia w zarządzaniu szkołami publicznymi (źródło internetowe 5). Podkreślano, że pierwszym obowiązkiem ministra edukacji jest wzmacnianie szkół publicznych, a wszystko, co głosi DeVos, czyni z niej słabego ich adwokata (źródło internetowe 6).

Odnieśmy te analizy do polskiego kontekstu (nie tylko z powodu nieuchronnego skojarzenia podobieństw znajdujących wyraz w nocnych obradach naszych parlamentów). Z konieczności będzie to odniesienie pobieżne, zarysowujące tylko pewną zauważalną, do niedawna silnie, a obecnie w zmącony i nie tak już jasny sposób, tendencję. Ta tendencja, to zbliżona do amerykańskiej dywersyfikacja podmiotów prowadzących instytucje oświatowe (od niemal całkowitego monopolu państwa do mieszaniny obejmującej dominujące w tym pejzażu samorządy, a poza nimi państwo, stowarzyszenia, wspólnoty religijne i podmioty prywatne) oraz - co jest najbliższe zjawisku czarteryzacji - powierzanie prowadzenia szkół publicznych podmiotom prywatnym lub stowarzyszeniom (Dziemianowicz-Bąk, Dzierzgowski, 2014). Wyłom stanowił tu program „ratowania” małych szkół wiejskich, które - jako nierentowne dla przeciążonych wydatkami oświatowymi lokalnych samorządów - mogły przetrwać jedynie pod warunkiem przejęcia przez stowarzyszenia lub osoby prywatne (Marzec-Holka, Rutkowska, 2012; Marzec-Holka, 2015). Podobnie jak w USA wiązało się to ze zmianą form zatrudnienia nauczycieli od momentu przejęcia przez podmioty niepubliczne nieobjętych już warunkami porozumień zbiorowych (Karta Nauczyciela). Ten wyłom został wykorzystany w ostatnich latach do przekazywania podmiotom prywatnym także szkół miejskich. Precedensowy przypadek to nowo wybudowana szkoła w jednej 
z dzielnic Gdańska, która przed otwarciem została na podstawie umowy przekazana do prowadzenia przez wyłonione w konkursie stowarzyszenie ${ }^{11}$. Tak jak charters zatrudnia ona nauczycieli w oparciu o regulacje ogólne (Kodeks pracy), ale - ściśle realizując założenia nieselekcyjnej polityki oświatowej miasta - mimo to przyciąga do siebie dzieci z rodzin o wyższym statusie społecznym.

Bez względu jednak na te tendencje w „normalnie” prowadzonych szkołach publicznych również w Polsce mamy do czynienia ze zjawiskami klasowej segregacji, co, jak precyzyjnie ilustrują badania Romana Dolaty, najwyraźniej zaznacza się w wielkomiejskich gimnazjach (Dolata, 2010). Jakie ma to znaczenie dla idei edukacji publicznej?

Podobnie jak w USA szkoły - szczególnie miejskie, gdzie prawo wyboru placówki dla dziecka prowadzi do klasowej polaryzacji - przestają być miejscami, w których ludzie należący do zróżnicowanych warstw czy klas społecznych mogą się uczyć wspólnego życia, a nawet tak prostej wiedzy jak ta, że wyniesione przez nich z rodzinnego domu wartości i przekonania nie są uniwersalne, że obok nich żyje mnóstwo ludzi myślących i odczuwających inaczej, w różny sposób wyobrażających sobie dobry świat.

W tym kontekście trzeba zwrócić uwagę na bardzo ważną i - na pierwszy rzut oka - paradoksalną, a wręcz trudną do zrozumienia, za to bardzo aktualną kwestię. Polityka społeczna kierowana neoliberalnymi wyobrażeniami o wadze rynkowej konkurencji i jednostkowej odpowiedzialności za dokonywane wybory (w tym wypadku edukacyjne) została zdecydowanie zakwestionowana w Polsce w wyborach parlamentarnych w 2015 roku wygranych przez Prawo i Sprawiedliwość (PiS) - partię odwołującą się do pomijanych wcześniej w publicznym dyskursie „Zwykłych Polaków”, a - mówiąc językiem socjologicznym - do klasy ludowej. Realizowana przez PiS „dobra zmiana” ma przywrócić tym grupom społecznym godność i należne miejsce w przestrzeni publicznej.

Można by się spodziewać, że - sprzyjający środowiskom miejskiej klasy średniej - styl poprzedniej polityki edukacyjnej zostanie w związku z tym zastąpiony polityką bardziej egalitarną, równościową, zapobiegającą nieuzasadnionym merytorycznie selekcjom ograniczającym szanse życiowe „gorzej urodzonych” dzieci.

Tymczasem polityka oświatowa PiS zmierza w stronę dokładnie przeciwną i rozbudowuje strategie selekcyjne systemu. Po pierwsze, zablokowano reformę mającą na celu wcześniejszy start szkolny, co jest jednoznacznie uznanym sposobem skutecznego zmniejszania różnicy kompetencji kulturowych warunkujących sukces szkolny dzieci rodziców o niższym poziomie wykształcenia. Po drugie,

11 Więcej o tym fenomenie: Mendel, 2017. 
skrócono okres obowiązkowego kształcenia ogólnego - z dawnych dziewięciu do obecnych ośmiu lat, co wyraźnie zmniejszy szanse ubiegania się dzieci z rodzin o niższym poziomie wykształcenia o sensowne wykształcenie akademickie. Po trzecie, po ukończeniu szkoły podstawowej znaczna część młodych ludzi zostanie skierowana do szkół zawodowych („przebranżowionych” na szkoły branżowe), co już w czasach PRL krytykowano jako strategię zamykania szans rozwoju edukacyjnego dla większości młodych ludzi, właśnie dla tych, do których odwołuje się polityka PiS. To chyba nie jest przypadek, że wszystkie te rozwiązania strukturalne są nastawione na hamowanie społecznej mobilności i są jednoznacznie antyrównościowe.

Dodajmy do tego, że jednocześnie wprowadzana reforma szkolnictwa wyższego również kładzie nacisk na rozwarstwienie jakości kształcenia akademickiego, na wydzielenie wąskiej grupy uczelni elitarnych i zdecydowane ograniczenie dostępności tego szczebla kształcenia dla osób - mówiąc językiem teorii Bourdieu - nieposiadających odpowiedniego kapitału kulturowego. W licznych wypowiedziach osób związanych z PiS lub z tą partią sympatyzujących, broniących założeń reformy, pojawiają się wypowiedzi, że odpowiednia jakość kształcenia akademickiego może być zagwarantowana tylko przez elitarne licea. Krótko mówiąc, koniec z masowym dostępem do wykształcenia średniego i koniec z masowym dostępem do studiów. Ta polityka edukacyjna oznacza zdecydowane zerwanie z „mrzonkami” o równości edukacyjnej. Z punktu widzenia wiedzy o roli edukacji w dążeniach do społecznej równości jest to polityka zdecydowanie i skrajnie sprzeczna z interesami tych grup społecznych, które - w swych deklaracjach - PiS podobno wspiera i które prawdopodobnie przyczyniły się do wyborczego sukcesu tej partii.

Czy jest jakieś wyobrażalne, racjonalne wytłumaczenie tej sprzeczności? Jaka ma być funkcja tak reformowanej szkoły publicznej?

Być może jednym z kluczy do tej zagadki jest przywoływane przez nas pojęcie godności. Inaczej mówiąc, PiS nie obiecuje ludziom równości, a na pewno nie obiecuje równości dostępu do bardziej atrakcyjnych (finansowo i ze względu na możliwości samorealizacji) zawodów i związanych z nimi profili kształcenia. Ma to być może związek z zapowiadaną strategią rozwoju przez reindustrializację, co będzie wymagało masowej „produkcji” klasy robotniczej. To z kolei wymaga studzenia aspiracji ogromnej większości uczniów, co zapewne tłumaczy zerwanie z powszechnym dostępem do kształcenia średniego. Duże prawdopodobieństwo buntu mas ludzi spychanych w ten sposób na niższe pozycje w społecznym podziale pracy ma być natomiast - prawdopodobnie - minimalizowane przez dwie powiązane ze sobą strategie: po pierwsze, przez symboliczne „dopieszczanie” 
nowego proletariatu - w tym obszarze pracuje antyelitarna propaganda kontrolowanych przez PiS mediów (przypomnijmy, kompletnie sprzeczna z jednoznacznie elitarnq polityką edukacyjną). W tym samym obszarze - godnościowym - mieści się też jednoznaczne zastępowanie kategorii społeczeństwa przez kategorię narodu; i ta transformacja nie może obyć się bez reformy treści kształcenia. Zapewne dla złagodzenia elitarystycznego charakteru reformy szkolnictwa wyższego (pomijając cele natury ideologicznej) w ustawie przyjętej przez Sejm w lipcu 2018 roku zawarto zapisy zobowiązujące uczelnie do wychowywania studentów - m.in. w duchu narodowym.

Po co takie przemieszczenie, do czego jest nam „potrzebne” w publicznym dyskursie zastępowanie społeczeństwa przez naród?

Naród to wspólnota symboliczna, emocjonalna, budowana przez stosunek do znaków, mitów i odpowiednio preparowanej (por.: spory o politykę muzealną, kulturalną itp.) narracji historycznej. Naród nie potrzebuje równości społecznej, w tym wyobrażonym typie wspólnoty równość dotyczy bowiem nie różnic statusu, a przeżywania symboli (por.: kary dla osób nietraktujących ich poważnie) i ostatecznie - śmierci na polu chwały. To najbardziej dostępna forma równości dla mas. Zupełnie niekonieczna zaś jest równość szans życiowych i równego dostępu do sensownej edukacji. To chyba jeden z największych paradoksów obecnej polityki państwa: powszechnie krytykowany na całym świecie za ukryte sprzyjanie nierównościom społecznym neoliberalizm zostaje oto zastąpiony przez jawnie sprzyjający nierównościom społecznym narodowy konserwatyzm.

Nie miałoby to jednak żadnych szans powodzenia, gdyby nie druga, kluczowa dla tej strategii politycznej taktyka zapobiegania buntowi: redukcja nierówności ekonomicznych. Nie jest ona jednak powiązana z pracą i płacą zależną od kwalifikacji, a z prokreacją. Obfity zasiłek dla rodzin mających więcej niż jedno dziecko może skutecznie ustabilizować projekt zamrożenia społecznej mobilności przez zamknięcie szans na zdobycie wyższych kwalifikacji dla większości społeczeństwa. Rządząca partia stawia się tu w roli „dobrych panów” (jak kiedyś wyraził się jej lider), to od jej woli zależy, kto uzyska odpowiednie dla przeżycia środki, a kto nie: matki rodzące wiele dzieci - tak; matki buntujące się z powodu braku środków na wychowanie tych dzieci, które urodziły się z niepełnosprawnością - zupełnie niekoniecznie. Krótko mówiąc, to nie zdobyte wysiłkiem edukacyjnym kompetencje zawodowe, nie indywidualna przedsiębiorczość, a już tym bardziej nie cywilna odwaga upominania się o swoje potrzeby - a zdyscyplinowana pracowitość w zaprojektowanych przez premiera megafabrykach i zdyscyplinowana rozrodczość w patriarchalnych rodzinach mają być gwarancją dobrego życia. 
Zabrzmi to ponuro, ale ten projekt społeczny wygląda tak, jakby PiS wynalazł sposób na jednoczesną przebudowę gospodarki (wielkie fabryki sterowane przez rządowe programy rozwojowe zamiast setek małych przedsiębiorstw napędzanych przez rozproszone innowacje), struktury społecznej (wyraźny podział na intelektualne, ale posłuszne elity - por.: rozbudowane w nowej „konstytucji nauki” zapisy o postępowaniu z pracownikami akademickimi w przypadku oskarżeń prokuratorskich i aresztowań i masę ludzi gotowych do pracy w fabrykach, przy jednoczesnym zachęcaniu kobiet do rodzenia dzieci, co zmniejszy presję na akceptowanie trudnej dla idei narodowej imigracji, ale co wymaga zaakceptowania przez kobiety redukcji ich aspiracji do macierzyństwa; stąd pewnie często komiczna walka z ,genderem”) i - niezbędnej dla powodzenia tych rewolucyjnych zamierzeń - kompletnej centralizacji decyzji. Jej realnym polem jest obecnie walka o kształt sądów i parlamentu, a niedługo rozpocznie się walka o kształt ustroju samorządowego. Wyrazistym jej symbolem jest natomiast idea Centralnego Portu Komunikacyjnego, który w miejsce rozproszonej sieci lotnisk, nadających dynamikę regionalnym strategiom rozwojowym, zbuduje jedno, ,za to wielkie” megalotnisko, które zredukuje dynamicznie rosnące porty regionalne do roli lokalnych portów krajowych; a samorządy - do roli wykonawców centralnego planu.

We wstępnej części tekstu wspominaliśmy, że jednym z czynników sprzyjających tworzeniu szkół publicznych było pojawienie się idei państw narodowych. Neoliberalna polityka edukacyjna poprzednich rządów, wraz z jej ideą równości szans - głośno proklamowaną, ale skrycie blokowaną przez pozornie niewinne strategie wyboru szkoły w oparciu o mierzalne kryteria jej jakości - została zastąpiona przez politykę narodową, w której nierówności społeczne są jawnie wzmacniane i stabilizowane, a szkoła publiczna ma je cementować przez wczesną i wprost zapowiedzianą dywersyfikację ścieżek kształcenia „dla mas” i „dla elit”, budując dla nich - w miejsce wspólnej przestrzeni relacji społecznych (dotychczas: rynku, społeczności lokalnych i społeczeństwa obywatelskiego) przestrzeń wspólnej narodowej mitologii. To też jest misja szkoły publicznej. Co z nią zrobimy?

\section{Bibliografia}

Berliner, D.C., Glass, G.V. i in. (2014). 50 myths \& lies that threaten America's public schools. The real crisis in education. New York: Teachers College Press.

Bourdieu, P., Passeron, J.-C. (1990). Reprodukcja. Elementy teorii systemu nauczania. Warszawa: PWN. 
Buras, K.L. (2015). Charter schools, race, and urban space: where the market meets grassroots resistance. New York: Routledge.

Cervinkova, H., Gołębniak, B. (red.). (2010). Badania w działaniu. Pedagogika i antropologia zaangażowane. Wrocław: Wydawnictwo Naukowe Dolnośląskiej Szkoły Wyższej.

Daly, A.J., Finnigan, K.S. (eds.). (2016): Thinking and Acting Systemically: Improving School Districts Under Pressure. Waszyngton: American Educational Research Association.

Dolata, R. (2010). Międzyszkolne zróżnicowanie wyników nauczania w szkołach podstawowych i gimnazjach. W: J. Łukasik, I. Nowosad, M.J. Szymański (red.), Edukacja. Równość czy jakość? Toruń: Wydawnictwo Adam Marszałek.

Dziemianowicz-Bąk, A., Dzierzgowski, J. (2014). Likwidacja szkół podstawowych oraz przekazywanie stowarzyszeniom. Kontekst, proces i skutki przemian edukacyjnych w społecznościach lokalnych na podstawie analizy studiów przypadku. Warszawa: IBE.

Jung-Miklaszewska, J., Rusakowska, D. (1995). Szkoły społeczne in statu nascendi. Warszawa: Instytut Badań Edukacyjnych.

Marzec-Holka, K., Rutkowska, A. (red.). (2012). Małe Szkoły w województwie kujawsko-pomorskim. Studium pedagogiczno-socjologiczne. Bydgoszcz: Wydawnictwo Uniwersytetu Kazimierza Wielkiego.

Marzec-Holka, K.(2015). Kapitał społeczny a wspólnoty wiejskie w obronie „małych szkół”. Przykład województwa kujawsko-pomorskiego. Bydgoszcz: Wydawnictwo Uniwersytetu Kazimierza Wielkiego.

Mendel, M., Szkudlarek, T. (2013). Kryzys jako dyskurs i narracja. Konteksty edukacyjne. Forum Oświatowe: Edukacja dla zmiany. Kryzysy, diagnozy, działania, 3(50), s.13-34.

Mendel, M. (2015). Szkoła poza szkołą. O odrywającym się desygnacie i postdemokratycznej wersji powszechnej edukacji. W: A. Szczurek-Boruta, B. Chojnacka-Synaszko (red.), Szkoła - kultura - środowisko lokalne. Toruń: Wydawnictwo Adam Marszałek, s. 59-78.

Mendel, M. (2017). Pedagogika miejsca wspólnego. Miasto i szkoła. Gdańsk: Wydawnictwo Naukowe Katedra.

Ornstein, A.C., Levine, D.U., Gutek, G. (2011). Foundation of Education. 11th edition. Belmont: WADSWORTH CENGAGE Learning.

Ravitch, D. (2013). Reign of Error: The Hoax of Privatization Movement and the Danger to America's Public Schools. New York: Random House.

Stahl, G. (2018). Ethnography of a Neoliberal School: Building Cultures of Success. New York-London: Routledge.

Szkudlarek, T.(2001). Ekonomia i etyka: przemieszczenia dyskursu edukacyjnego. Teraźniejszość - Człowiek - Edukacja. Numer specjalny: „Normatywność, etyczność, zaangażowanie”.

\section{Źródła internetowe:}

http://dobraedukacja.edu.pl/pl/akademie/.

http://www.edukacjademokratyczna.pl/szkola-demokratyczna.

http://www.reclaimourschools.org/sites/default/files/AROS\%20Community\%20Schools\%20def_1.pdf. 
http://www.vox.com/policy-and-politics/2017/2/7/14529608/betsy-devos-defense-critics-wrong-public-schools.

http://wiadomosci.onet.pl/swiat/usa-betsy-devos-zatwierdzona-jako-minister-edukacji/ ebphk9w.

http://www.vox.com/policy-and-politics/2017/2/7/14529608/betsy-devos-defense-critics-wrong-public-schools. 